Article

\title{
An Aqueous Extract of Tuberaria lignosa Inhibits Cell Growth, Alters the Cell Cycle Profile, and Induces Apoptosis of NCI-H460 Tumor Cells
}

\author{
Joana M. Pereira ${ }^{1}$, Vanessa Lopes-Rodrigues ${ }^{2,3,4}$, Cristina P. R. Xavier ${ }^{2,3}$, M. João Lima ${ }^{1}$, \\ Raquel T. Lima ${ }^{2,3,5}$, Isabel C. F. R. Ferreira ${ }^{6, *}$ and M. Helena Vasconcelos $1,2,3, *$ \\ 1 Department of Biological Sciences, FFUP-Faculty of Pharmacy of the University of Porto, \\ Rua de Jorge Viterbo Ferreira 228, Porto 4050-313, Portugal; joanita_12@live.com.pt (J.M.P.); \\ mjpclima@gmail.com (M.J.L.) \\ 2 i3S-Instituto de Investigação e Inovação em Saúde da Universidade do Porto, Rua Alfredo Allen 208, \\ Porto 4200-135, Portugal; vrodrigues@ipatimup.pt (V.L.-R.); cristinax@ipatimup.pt (C.P.R.X.); \\ rlima@ipatimup.pt (R.T.L.) \\ 3 Cancer Drug Resistance Group, IPATIMUP_Institute of Molecular Pathology and Immunology of the \\ University of Porto, Porto 4200-135, Portugal \\ 4 ICBAS-UP-Institute of Biomedical Sciences Abel Salazar, University of Porto, Porto 4050-313, Portugal \\ 5 Department of Pathology and Oncology, FMUP-Faculty of Medicine of the University of Porto, \\ Alameda Prof. Hernâni Monteiro, Porto 4200-319, Portugal \\ 6 Mountain Research Centre (CIMO), Polytechnic Institute of Bragança, Apartado 1172, \\ Bragança 5301-855, Portugal \\ * Correspondence: iferreira@ipb.pt (I.C.F.R.F.); hvasconcelos@ipatimup.pt (M.H.V.); \\ Tel.: +351-273-303-219 (I.C.F.R.F.); +351-220-408-800 (M.H.V.); Fax: +351-273-325-405 (I.C.F.R.F.)
}

Academic Editor: Derek J. McPhee

Received: 16 April 2016; Accepted: 30 April 2016; Published: 6 May 2016

\begin{abstract}
Tuberaria lignosa (Sweet) Samp. is found in European regions, and has antioxidant properties due to its composition in ascorbic acid and phenolic compounds. Given its traditional use and antioxidant properties, the tumor cell growth inhibitory potential of aqueous extracts from T. lignosa (prepared by infusion and decoction) was investigated in three human tumor cell lines: MCF-7 (breast adenocarcinoma), NCI-H460 (non-small cell lung cancer), and HCT-15 (human colorectal adenocarcinoma). Both extracts inhibited the growth of these cell lines; the most potent one being the T. lignosa extract obtained by infusion in the NCI-H460 cells ( $\mathrm{GI}_{50}$ of approximately $50 \mu \mathrm{g} / \mathrm{mL}$ ). Further assays were carried out with this extract in NCI-H460 cells. At $100 \mu \mathrm{g} / \mathrm{mL}$ or $150 \mu \mathrm{g} / \mathrm{mL}$ it caused an increase in the percentage of cells in the G0/G1 phase and a decrease of cells in S phase of the cell cycle. Additionally, these concentrations caused an increase in the percentage of apoptotic cells. In agreement, a decrease in total poly (ADP-ribose) polymerase (PARP) and pro-caspase 3 levels was found. In conclusion, the T. lignosa extract obtained by infusion was more potent in NCI-H460 cells, altering the cell cycle progression and inducing apoptosis. This work highlights the importance of $T$. lignosa as a source of bioactive compounds with tumor cell growth inhibitory potential.
\end{abstract}

Keywords: T. lignosa extracts; inhibition of tumor cell growth; $\mathrm{H} 460$ tumor cell line; cell cycle; apoptosis

\section{Introduction}

Herbal drugs have been extensively used for the treatment of several diseases all over the world [1-3]. In particular, the interest in plants as a natural source of pharmaceutical compounds with antitumor activity has increased in the past years. Indeed, several anti-cancer agents derived from plants (such as vinca alkaloids, epipodophyllotoxins derivatives, taxanes, and the campothecin 
derivatives) have been discovered in the last decades [1,2,4-9]. Furthermore, several plant-derived anticancer agents have achieved pre-clinical or clinical development $[7,8,10,11]$.

Tuberaria lignosa (Sweet) Samp. (Rockrose like species) is a plant found in the west and south part of Europe and is mostly present in the Iberian Peninsula, where it is known as "alcária" or "erva loba" $[12,13]$. This plant has been used in traditional medicine to treat several diseases, such as gastrointestinal disorders, viral infections, and skin infections, among others [12,13]. The preparation of medicinal infusions and decoctions may involve the use of the whole plant or just some parts of the plant and may be prepared fresh or shade-dried [12]. The chemical composition of T. lignosa aqueous extracts, obtained by infusion and decoction, has been previously analyzed and compared by some of the authors [12,13]. It has been demonstrated that infusions obtained from freeze-dried samples have higher concentrations in compounds such as free sugars (e.g., fructose, glucose, sucrose, trehalose, and raffinose) and lower concentrations of ascorbic acid and phenolic compounds (including ellagic acid derivatives and flavonoids) when compared with decoctions obtained from freeze-dried samples and infusions prepared from shade-dried samples [12]. Additionally, the freeze-dried samples also proved to have higher antioxidant activity than the other samples and even higher than trolox, the positive control used in the referred study [12]. Both infusion and decoction samples from T. lignosa have bioactive molecules, such as phenolic compounds and ascorbic acid, which can explain their antioxidant activity [12-15].

In spite of its content in such bioactive molecules, to our knowledge the tumor cell growth inhibitory potential of this plant has never been studied. Therefore, the main objective of this work was to investigate the tumor cell growth inhibitory effect of two aqueous extracts prepared by infusion and decoction from Tuberaria lignosa in different human tumor cell lines: MCF-7 (breast adenocarcinoma), NCI-H460 (non-small cell lung cancer), and HCT-15 (human colorectal adenocarcinoma). In addition, the cellular effects of the T. lignosa extract obtained by infusion on cell cycle profile and apoptosis were studied in more detail in the most sensitive cell line (NCI-H460).

\section{Results and Discussion}

\subsection{T. lignosa Extracts Inhibited Tumor Cell Growth}

The sulforhodamine B (SRB) assay was carried out in order to determinate the in vitro cytotoxicity of the T. lignosa aqueous extracts, prepared by decoction and infusion, in three different human tumor cell lines, using doxorubicin as the positive control. The results showed that $T$. lignosa extract obtained by infusion was the most potent extract in the MCF-7 and in the NCI-H460 cells (Table 1). However, in the HCT-15 cells both extracts had similar effect. Overall, the most potent extract was the infusion of T. lignosa in the NCI-H460 cells. This is probably due to the different chemical composition of the extracts, namely in phenolic acid derivatives, ellagic acid derivatives, and flavonoids, with infusion presenting higher content in phenolic acid derivatives [12]. Therefore, the following analyses were conducted with this extract (infusion). The cell line selected to continue the studies was the NCI-H460, since this was the cell line in which the infusion extract was more potent and since it is representative of lung cancer which has high incidence and is still one of the most common cause of cancer related deaths [16].

Table 1. $\mathrm{GI}_{50}$ concentrations of T. lignosa extracts in three human tumor cell lines.

\begin{tabular}{cccc}
\hline \multirow{2}{*}{ Extracts } & \multicolumn{4}{c}{ GI $_{\text {50 }}$ Concentrations $(\mu \mathrm{g} / \mathrm{mL})$ in Different Cell Lines } \\
\cline { 2 - 4 } & MCF-7 & HCT-15 & NCI-H460 \\
\hline Decoction & $135.1 \pm 14.6$ & $47.0 \pm 2.2$ & $103.7 \pm 19.0$ \\
Infusion & $72.9 \pm 10.2$ & $57.5 \pm 8.2$ & $43.4 \pm 7.8$ \\
\hline
\end{tabular}

$\mathrm{GI}_{50}$ concentrations correspond to the mean \pm S.E. of at least three independent experiments, carried out with duplicates. Doxorubicin was used as a positive control, with the following results having been obtained: $56.3 \mathrm{nM} \pm 14.5$ in MCF-7 cells and $89.3 \mathrm{nM} \pm 16.7$ in NCI-H460 cells. GI refers to the concentration that inhibits $50 \%$ of net cell growth. S.E. refers to standard error. 
The compounds isolated from plants with potential activity against cancer have shown multiple mechanisms of action, such as interference with death signals thereby inducing apoptosis, disturbance of multiple cellular signaling pathways, regulation of the cell cycle, and/or interference with cellular invasion and metastasis [3,17-21]. For this reason, this study has further investigated the effect of the infusion extract of $T$. lignosa on cell cycle and apoptosis.

\subsection{T. lignosa Infusion Extract Blocked the Cell Cycle Progression of NCI-H460 Cells}

To gain insight into the cytotoxic mechanism of action of the T. lignosa extract obtained by infusion, its effect on the cell cycle was analyzed. For this, to assess a possible dose-dependent effect, NCI-H460 cells were treated with increasing concentrations of the extract: $50 \mu \mathrm{g} / \mathrm{mL}, 100 \mu \mathrm{g} / \mathrm{mL}$, and $150 \mu \mathrm{g} / \mathrm{mL}$ (approximately the $\mathrm{GI}_{50}, 2 \times \mathrm{GI}_{50}$, and $3 \times \mathrm{GI}_{50}$ concentrations, respectively, with GI referring to the concentration that inhibits $50 \%$ of net cell growth). Controls for the solvent of the extract $\left(\mathrm{H}_{2} \mathrm{O}\right)$ were included. Results showed that treatment of the NCI-H460 cells with the highest tested concentrations $(100 \mu \mathrm{g} / \mathrm{mL}$ or $150 \mu \mathrm{g} / \mathrm{mL})$ of the extract caused a statistically significant increase in the percentage of cells in the G0/G1 phase of the cell cycle and a statistically significant decrease in the percentage of the cells in the $S$ phase of the cell cycle (Figure 1). In addition, for the $100 \mu \mathrm{g} / \mathrm{mL}$ concentration a statistically significant decrease in the G2/M phase of the cell cycle was also observed. This data suggested that T. lignosa infusion extract blocked the cell cycle progression of the NCI-H460 cells, having a significant effect at $100 \mu \mathrm{g} / \mathrm{mL}$ and $150 \mu \mathrm{g} / \mathrm{mL}$.

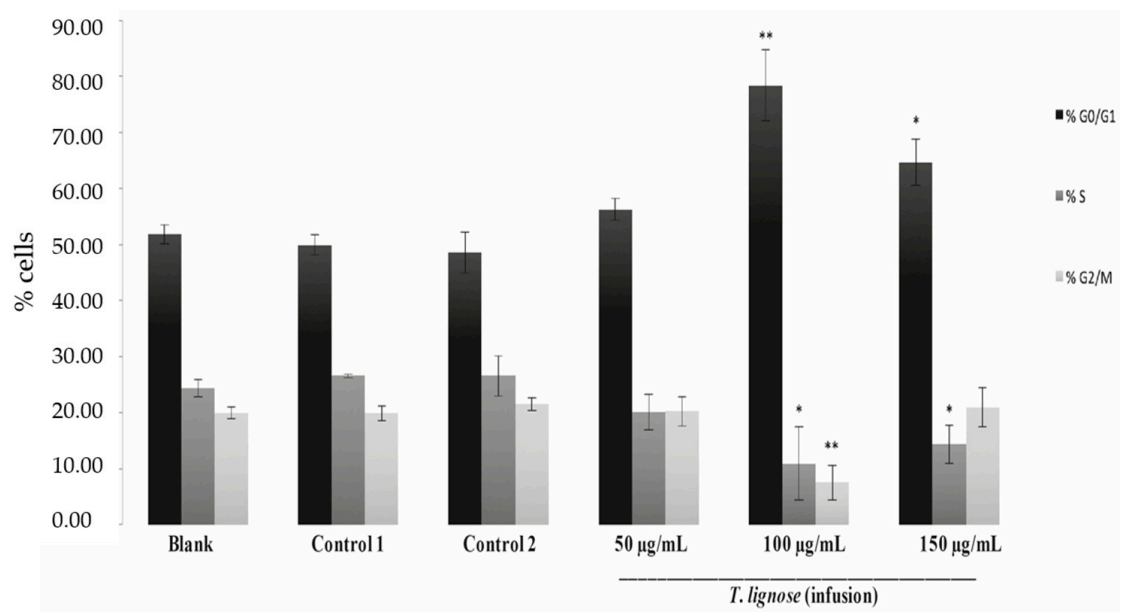

Figure 1. Effect of T. lignosa infusion extract on NCI-H460 cell cycle distribution. Cells were treated for $48 \mathrm{~h}$ with complete medium (Blank), with the extract $(50 \mu \mathrm{g} / \mathrm{mL}, 100 \mu \mathrm{g} / \mathrm{mL}$, or $150 \mu \mathrm{g} / \mathrm{mL}$ ), or with Control treatments (the two highest vehicle, $\mathrm{H}_{2} \mathrm{O}$, concentrations). Results are the mean \pm SEM of four independent experiments. ${ }^{*} p \leqslant 0.05$ and ${ }^{* *} p \leqslant 0.01$ Blank vs. Treatment.

Various plant extracts with recognized antitumor activity have similar effects, arresting cells in the G0/G1 phase of the cell cycle, such as ginseng extract [22], the extract of Tinospora cordifolia [23], or the Marsdenia tenacissima extract [24].

\subsection{T. lignosa Infusion Extract Induced Apoptosis in NCI-H460 Cells}

The effect of T. lignosa infusion extract on cellular apoptosis was also analyzed by flow cytometry analysis of Annexin V-FITC and propidium iodide (PI) labeling/staining. Results (Table 2) showed an increase in the percentage of cells undergoing apoptosis after treatment with the extract, with statistically significant results observed for the $150 \mu \mathrm{g} / \mathrm{mL}$ concentration treatment. Treatment of cells with $100 \mu \mathrm{g} / \mathrm{mL}$ of extract also caused an increase in apoptosis to nearly twice the control levels, even though this increase was not considered statistically significant. The reason why cellular treatment with $100 \mu \mathrm{g} / \mathrm{mL}$ of extract caused statistically significant alterations in cell cycle but not in apoptosis 
is possibly because the effect on the cell cycle might precede the effect on apoptosis. Time-course experiments would confirm this hypothesis. Nevertheless, overall this data demonstrated that this extract caused apoptosis in NCI-H460 cells.

Table 2. Apoptosis levels in NCI-H460 cells treated with infusion extract of T. lignosa.

\begin{tabular}{ccc}
\hline \multicolumn{2}{c}{ Conditions } & \% Apoptosis \\
\hline \multicolumn{2}{c}{ Blank } & $9.51 \pm 0.9$ \\
\hline \multirow{2}{*}{ Control $\left(\mathrm{H}_{2} \mathrm{O}\right)$} & Control 1 & $9.45 \pm 0.3$ \\
& Control 2 & $12.7 \pm 1.9$ \\
\hline \multirow{2}{*}{ T. lignosa (infusion) } & $50 \mu \mathrm{g} / \mathrm{mL}$ & $15.8 \pm 7.1$ \\
& $100 \mu \mathrm{g} / \mathrm{mL}$ & $22.0 \pm 6.1$ \\
& $150 \mu \mathrm{g} / \mathrm{mL}$ & $34.7 \pm 7.9 *$ \\
\hline
\end{tabular}

Results are the mean \pm SEM of three independent experiments. ${ }^{*} p \leqslant 0.05$ blank $v$ s. treatment. Control treatments correspond to the two highest vehicle $\left(\mathrm{H}_{2} \mathrm{O}\right)$ concentrations.

To confirm the effect on apoptosis, the effect of this extract on the expression levels of cellular proteins involved in apoptosis was analyzed. Results from the Western blot analysis showed a decrease in the levels of total poly (ADP-ribose) polymerase (PARP) and pro-caspase 3 (Figure 2). These results further confirm that the T. lignosa infusion extract induced apoptosis in NCI-H460 cells. Indeed, a reduction in the total levels of PARP is an accepted event in cellular apoptosis $[25,26]$. Unfortunately, our antibody does not detect the cleaved form of caspase-3. However, the observed reduction in pro-caspase 3 is indicative that the extract induced the intrinsic pathway of apoptosis $[27,28]$.
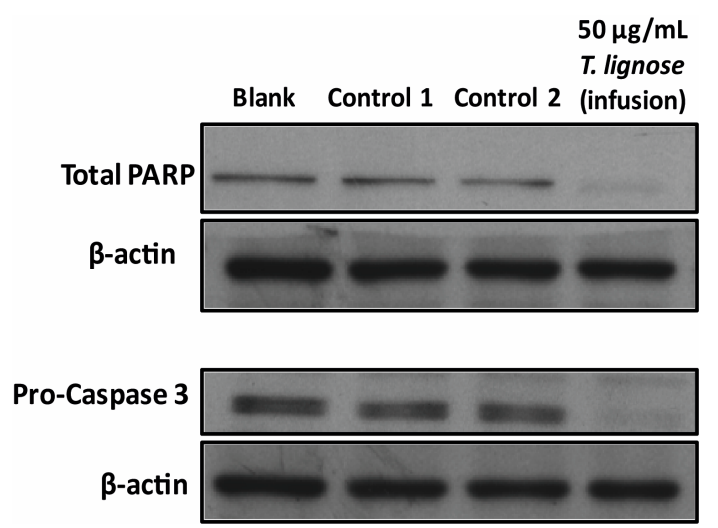

Figure 2. Effect of T. lignosa infusion extract on the NCI-H460 cellular expression levels of total PARP-1 and pro-caspase-3, analyzed by Western blot. Cells were treated for $48 \mathrm{~h}$ with complete medium (Blank), Controls (vehicle of the extract, $\mathrm{H}_{2} \mathrm{O}$ ), or with $50 \mu \mathrm{g} / \mathrm{mL}$ of the extract. $\beta$-actin was used as loading control. Blots are representative of two independent experiments.

\section{Material and Methods}

\subsection{Samples and Preparation of the T. lignosa Extracts}

T. lignosa was collected in Miranda do Douro (Trás-os-Montes, Northeastern Portugal), as referred in Pinela et al., 2012 [12]. The preparation of decoctions and infusions followed the protocol previously described by Pinela et al., 2012 [12]. Stock solutions of the extract were prepared in water and stored at $-20^{\circ} \mathrm{C}$. Both aqueous extracts were previously characterized by some of the authors in terms of phenolic compounds [12]. 


\subsection{Cell Culture}

Three different human tumor cell lines were used: MCF-7 (breast adenocarcinoma), NCI-H460 (non-small cell lung cancer), and HCT-15 (human colorectal adenocarcinoma). All of these cells were maintained in RPMI-1640 medium with Glutamax ${ }^{\mathrm{TM}}$, supplemented with 1 M 4-(2-Hydroxyethyl) piperazine-1-ethanesulfonic acid (HEPES) buffer and fetal bovine serum (FBS). The FBS concentration used was $5 \%$ for the cell growth inhibition assay and $10 \%$ for the remaining assays. The monolayer cultures were kept at $37^{\circ} \mathrm{C}$ in a humidified incubator with $5 \% \mathrm{CO}_{2}$. Cells were routinely observed with a microscope (Nikon eclipse TS100 microscope, Nikon Instruments Europe BV, Amsterdam, The Netherlands). All the experiments described were performed only when exponentially growing cells presented more than $90 \%$ viability.

\subsection{Cell Growth Inhibition Assay}

The SRB assay was adapted from the procedure used in the NCI's in vitro anti-cancer drug screening $[29,30]$. Briefly, cells were plated in 96-well plates at their previously determined optimal concentrations $\left(5.0 \times 10^{4}\right.$ cells $/ \mathrm{mL}$ for NCI-H460 and MCF-7 cells and $1.0 \times 10^{5}$ cells $/ \mathrm{mL}$ for HCT-15 cells) and incubated for $24 \mathrm{~h}$. Cells were then treated with five serial dilutions of T. lignosa infusion and T. lignosa decoction, ranging from $400 \mu \mathrm{g} / \mathrm{mL}$ to $25 \mu \mathrm{g} / \mathrm{mL}$. Doxorubicin was used as a positive control (ranging from $150 \mathrm{nM}$ to $9.37 \mathrm{nM}$ ). The effect of the solvent of the extracts (water) on the growth of the cell lines was also evaluated by treating cells with the maximum concentration of water used. Following $48 \mathrm{~h}$ incubation with the extract, plates were fixed by adding ice-cold $10 \%$ ice cold trichloroacetic acid (TCA) ( $w / v$, final concentration, Panreac, Barcelona, Spain) and stained with $1 \%$ SRB (Sigma Aldrich, St. Louis, MO, USA) in 1\% $(v / v)$ acetic acid. Bound dye was solubilized by adding $10 \mathrm{mM}$ Tris base solution (Sigma Aldrich) and finally the absorbance was measured at $510 \mathrm{~nm}$ in a microplate reader (BioTek ${ }^{\circledR}$ Synergy HT, Winooski, VT, USA). Using the SRB assay, the $\mathrm{GI}_{50}$ concentration (concentration that inhibits $50 \%$ of net cell growth) was determined for $T$. lignosa infusion and decoction extracts in each cell line.

\subsection{Preparation of Cells for Other Analyses}

For the analysis of the cell cycle, apoptosis, or Western blot, the NCI-H460 cells were plated at $1.5 \times 10^{5}$ cells/well in-well plates and incubated for $24 \mathrm{~h}$. Cells were then treated with different concentrations of the T. lignosa infusion extract: $50 \mu \mathrm{g} / \mathrm{mL}$ (approximately the $\mathrm{GI}_{50}$ concentration), $100 \mu \mathrm{g} / \mathrm{mL}$ (approximately twice the $\mathrm{GI}_{50}$ ), and/or $150 \mu \mathrm{g} / \mathrm{mL}$ (approximately three times the $\mathrm{GI}_{50}$ ). Blank cells (treated with medium) and Control cells (treated with a concentration of water corresponding to the treatment with $100 \mu \mathrm{g} / \mathrm{mL}$-Control 1, or $150 \mu \mathrm{g} / \mathrm{mL}-$ Control 2) were also included. After treatment, cells were trypsinized and centrifuged at $1200 \mathrm{rpm}$ for $5 \mathrm{~min}$. Cells were then processed according to the procedures described below.

\subsection{Analysis of Cell Cycle Profile}

Cells were washed in PBS, fixed with ice-cold $70 \%$ ethanol, and stored at $4{ }^{\circ} \mathrm{C}$ for at least $12 \mathrm{~h}$. Next, the cells were centrifuged ( $5 \mathrm{~min}$ at $1200 \mathrm{rpm}$ ) and the pellets were re-suspended in a solution of PBS containing $5 \mu \mathrm{g} / \mathrm{mL}$ propidium iodide and $0.1 \mathrm{mg} / \mathrm{mL}$ RNase A. Cellular DNA content was analyzed by flow cytometry and the percentage of cells in the G0/G1, S, and G2/M phases of the cell cycle were determined using the BD Accuri ${ }^{\mathrm{TM}} \mathrm{C} 6$ Flow cytometer (BD Biosciences) after cell debris and aggregates exclusion and plotting at least 20,000 events per sample [31,32]. All data was analyzed using the FlowJo software (version 7.6.5, Tree Star, Inc., Ashland, OR, USA). 


\subsection{Analysis of Apoptosis}

For the analysis of apoptosis, cell pellets were washed and re-suspended in $1 \mathrm{~mL}$ of PBS. Following centrifugation, cells were processed for apoptosis analysis with the Annexin V-FITC Apoptosis Detection Kit (eBioscience) by resuspension in buffer solution, as indicated by the manufacturer. Cells were then incubated for $10 \mathrm{~min}$ with Human Annexin V-FICT and further incubated for $5 \mathrm{~min}$ with propidium iodide. Cells were analyzed by flow cytometry using the BD Accuri ${ }^{\mathrm{TM}}$ C6 Flow cytometer and respective software, plotting at least 20,000 events per sample [33,34]

\subsection{Analysis of Protein Expression}

For the analysis of protein expression, cell pellets were washed and resuspended in PBS. Cells were centrifuged and pellets were stored at $-20^{\circ} \mathrm{C}$. Cell pellets were then lysed in Winman's buffer containing 1\% NP-40, $0.1 \mathrm{M}$ Tris- $\mathrm{HCl} \mathrm{pH}$ 8.0, $0.15 \mathrm{M} \mathrm{NaCl}$, and $5 \mathrm{mM}$ EDTA, complemented with protease inhibitor cocktail (Roche). The total protein content was quantified using the $\mathrm{DC}^{\mathrm{TM}}$ Protein Assay kit (Bio-Rad, Hercules, CA, USA) according to manufacturer's instructions. Protein lysate (20 $\mu \mathrm{g})$ were loaded on $12 \%$ SDS-PAGE gel and transferred into a nitrocellulose membrane (GE Healthcare, Cleveland, OH, USA). The following primary antibodies were used: rabbit anti-PARP-1 (1:2000, sc-7150, Santa Cruz Biotechnology, Heidelberg, Germany), mouse anti-Caspase 3 (1:2000, 05-654, Merck Millipore, Darmstadt, Germany), and goat anti-actin (1:2000, sc-1616, Santa Cruz Biotechnology). The corresponding secondary antibodies were: anti-rabbit IgG-HRP, anti-mouse IgG-HRP, or anti-goat IgG-HRP (1:2000, Santa Cruz Biotechnology). The Amersham ${ }^{\mathrm{TM}}$ ECL Western Blotting Detection Reagents (GE Healthcare), the High Performance Chemiluminescence Film (GE Healthcare), and the Kodak GBX developer and fixer (Sigma) were used for signal detection [35,36].

\subsection{Statistical Analysis}

Three replicates of each aqueous extract were used. The data was statistically analyzed using the two-tailed paired Student's $t$-test.

\section{Conclusions}

The obtained results show that both infusion and decoction extracts from the plant T. lignosa caused reduction in the growth of three human tumor cell lines. To our knowledge, this is the first report of such an activity for this plant. The most potent effect was observed with the infusion extract in the NCI-H460 cells. The effect of this extract on these cells was due to alterations in the cell cycle profile and to induction of cellular apoptosis. Therefore, the data here presented highlights the interest of this plant as a possible source of natural bioactive compounds with tumor cell growth inhibitory potential. It would be interesting to isolate the compounds present in the infusion extract of this plant and to identify which one(s) are responsible for the observed effects in this tumor cell line. It would also be of interest to extend this study to other extracts of this plant and other cell lines.

Acknowledgments: This work was financed by FEDER-Fundo Europeu de Desenvolvimento Regional funds through the COMPETE 2020-Operacional Programme for Competitiveness and Internationalisation (POCI), Portugal 2020, and by Portuguese funds through FCT—Fundação para a Ciência e a Tecnologia/ Ministério da Ciência, Tecnologia e Inovação in the framework of the project "Institute for Research and Innovation in Health Sciences" (POCI-01-0145-FEDER-007274). The authors thank the Portuguese Foundation for Science and Technology (FCT) for the PhD grant of V.L.-R. (SFRH/BD/87646/2012) and for the post-doc grant of R.T.L. (SFRH/BPD/68787/2010).

Author Contributions: The contributions of the respective authors are as follows: J.M.P. performed most of the experiments and contributed to writing the manuscript; M.J.L. contributed to the cell growth inhibitory experiments; V.L.-R. performed the cell cycle and apoptosis analysis in the flow cytometer; C.P.R.X. performed the Western blots and contributed to writing the manuscript; R.T.L. contributed to data analysis; M.H.V. and I.C.F.R.F. conceived the study, supervised the experiments, and contributed to writing the manuscript. All the authors read and approved the final manuscript.

Conflicts of Interest: The authors declare no conflict of interest. 


\section{References}

1. Cragg, G.M.; Newman, D.J. Plants as a source of anti-cancer agents. J. Ethnopharmacol. 2005, 100, 72-79. [CrossRef] [PubMed]

2. Cragg, G.M.; Newman, D.J. Natural products: A continuing source of novel drug leads. Biochim. Biophys. Acta 2014, 1830, 3670-3695. [CrossRef] [PubMed]

3. Yin, S.Y.; Wei, W.C.; Jian, F.Y.; Yang, N.S. Therapeutic applications of herbal medicines for cancer patients. Evid. Based Complement. Altern. Med. 2013, 2013, 302426. [CrossRef] [PubMed]

4. Desai, A.G.; Qazi, G.N.; Ganju, R.K.; El-Tamer, M.; Singh, J.; Saxena, A.K.; Bedi, Y.S.; Taneja, S.C.; Bhat, H.K. Medicinal plants and cancer chemoprevention. Curr. Drug Metab. 2008, 9, 581-591. [CrossRef] [PubMed]

5. Sultana, S.; Asif, H.M.; Nazar, H.M.; Akhtar, N.; Rehman, J.U.; Rehman, R.U. Medicinal plants combating against cancer-A green anticancer approach. Asian Pac. J. Cancer Prev. 2014, 15, 4385-4394. [CrossRef] [PubMed]

6. Xavier, C.P.; Pereira-Wilson, C. Medicinal plants of the genuses Salvia and Hypericum are sources of anticolon cancer compounds: Effects on PI3K/Akt and MAP kinases pathways. PharmaNutrition 2015. [CrossRef]

7. Mondal, S.; Bandyopadhyay, S.; Ghosh, M.K.; Mukhopadhyay, S.; Roy, S.; Mandal, C. Natural products: Promising resources for cancer drug discovery. Anticancer Agents Med. Chem. 2012, 12, 49-75. [CrossRef] [PubMed]

8. Prakash, O.; Kumar, A.; Kumar, P.; Ajeet. Anticancer potential of plants and natural products: A review. Am. J. Pharmacol. Sci. 2013, 1, 104-115.

9. Sakarkar, D.M.; Deshmukh, V.N. Ethnopharmacological review of traditional medicinal plants for anticancer activity. Int. J. PharmTech. Res. 2011, 3, 298-308.

10. Wirger, A.; Perabo, F.G.; Burgemeister, S.; Haase, L.; Schmidt, D.H.; Doehn, C.; Mueller, S.C.; Jocham, D. Flavopiridol, an inhibitor of cyclin-dependent kinases, induces growth inhibition and apoptosis in bladder cancer cells in vitro and in vivo. Anticancer Res. 2005, 25, 4341-4347. [PubMed]

11. Hosseini, A.; Ghorbani, A. Cancer therapy with phytochemicals: Evidence from clinical studies. Avicenna J. Phytomed. 2015, 5, 84-97. [PubMed]

12. Pinela, J.; Barros, L.; Duenas, M.; Carvalho, A.M.; Santos-Buelga, C.; Ferreira, I.C. Antioxidant activity, ascorbic acid, phenolic compounds and sugars of wild and commercial tuberaria lignosa samples: Effects of drying and oral preparation methods. Food Chem. 2012, 135, 1028-1035. [CrossRef] [PubMed]

13. Pinela, J.; Antonio, A.L.; Barros, L.; Barreira, J.C.M.; Carvalho, A.M.; Oliveira, M.B.P.P.; Santos-Buelga, C.; Ferreira, I.C.F.R. Combined effects of gamma-irradiation and preparation method on antioxidant activity and phenolic composition of tuberaria lignosa. RSC Adv. 2015, 5, 14756-14767. [CrossRef]

14. Huang, W.Y.; Cai, Y.Z.; Zhang, Y. Natural phenolic compounds from medicinal herbs and dietary plants: Potential use for cancer prevention. Nutr. Cancer 2010, 62, 1-20. [CrossRef] [PubMed]

15. Du, J.; Cullen, J.J.; Buettner, G.R. Ascorbic acid: Chemistry, biology and the treatment of cancer. Biochim. Biophys. Acta 2012, 1826, 443-457. [CrossRef] [PubMed]

16. Siegel, R.L.; Miller, K.D.; Jemal, A. Cancer statistics, 2015. CA Cancer J. Clin. 2015, 65, 5-29. [CrossRef] [PubMed]

17. Safarzadeh, E.; Sandoghchian Shotorbani, S.; Baradaran, B. Herbal medicine as inducers of apoptosis in cancer treatment. Adv. Pharm. Bull. 2014, 4, 421-427. [PubMed]

18. Xavier, C.P.; Lima, C.F.; Fernandes-Ferreira, M.; Pereira-Wilson, C. Salvia fruticosa, salvia officinalis, and rosmarinic acid induce apoptosis and inhibit proliferation of human colorectal cell lines: The role in mapk/erk pathway. Nutr. Cancer 2009, 61, 564-571. [CrossRef] [PubMed]

19. Xavier, C.P.; Lima, C.F.; Fernandes-Ferreira, M.; Pereira-Wilson, C. Hypericum androsaemum water extract inhibits proliferation in human colorectal cancer cells through effects on map kinases and PI3K/Akt pathway. Food Funct. 2012, 3, 844-852. [CrossRef] [PubMed]

20. Sarkar, F.H.; Li, Y.; Wang, Z.; Kong, D. Cellular signaling perturbation by natural products. Cell. Signal. 2009, 21, 1541-1547. [CrossRef] [PubMed]

21. Neergheen, V.S.; Bahorun, T.; Taylor, E.W.; Jen, L.S.; Aruoma, O.I. Targeting specific cell signaling transduction pathways by dietary and medicinal phytochemicals in cancer chemoprevention. Toxicology 2010, 278, 229-241. [CrossRef] [PubMed] 
22. Kang, M.R.; Kim, H.M.; Kang, J.S.; Lee, K.; Lee, S.D.; Hyun, D.H.; In, M.J.; Park, S.K.; Kim, D.C. Lipid-soluble ginseng extract induces apoptosis and G0/G1 cell cycle arrest in NCI-H460 human lung cancer cells. Plant. Foods Hum. Nutr. 2011, 66, 101-106. [CrossRef] [PubMed]

23. Mishra, R.; Kaur, G. Tinospora cordifolia induces differentiation and senescence pathways in neuroblastoma cells. Mol. Neurobiol. 2015, 52, 719-733. [CrossRef] [PubMed]

24. Fan, W.; Sun, L.; Zhou, J.Q.; Zhang, C.; Qin, S.; Tang, Y.; Liu, Y.; Lin, S.S.; Yuan, S.T. Marsdenia tenacissima extract induces G0/G1 cell cycle arrest in human esophageal carcinoma cells by inhibiting mitogen-activated protein kinase (MAPK) signaling pathway. Chin. J. Nat. Med. 2015, 13, 428-437. [CrossRef]

25. Park, S.R.; Chen, A. Poly(adenosine diphosphate-ribose) polymerase inhibitors in cancer treatment. Hematol. Oncol. Clin. North. Am. 2012, 26, 649-670. [CrossRef] [PubMed]

26. Soldatenkov, V.A.; Potaman, V.N. DNA-binding properties of poly(ADP-ribose) polymerase: A target for anticancer therapy. Curr Drug Targets 2004, 5, 357-365. [CrossRef] [PubMed]

27. Green, D.R.; Llambi, F. Cell death signaling. Cold Spring Harb. Perspect. Biol. 2015, 7. [CrossRef] [PubMed]

28. Goldar, S.; Khaniani, M.S.; Derakhshan, S.M.; Baradaran, B. Molecular mechanisms of apoptosis and roles in cancer development and treatment. Asian Pac. J. Cancer Prev. 2015, 16, 2129-2144. [CrossRef] [PubMed]

29. Vichai, V.; Kirtikara, K. Sulforhodamine B colorimetric assay for cytotoxicity screening. Nat. Protoc. 2006, 1, 1112-1116. [CrossRef] [PubMed]

30. Neves, M.P.; Cidade, H.; Pinto, M.; Silva, A.M.; Gales, L.; Damas, A.M.; Lima, R.T.; Vasconcelos, M.H.; de Sao Jose Nascimento, M. Prenylated derivatives of baicalein and 3,7-dihydroxyflavone: Synthesis and study of their effects on tumor cell lines growth, cell cycle and apoptosis. Eur. J. Med. Chem. 2011, 46, 2562-2574. [CrossRef] [PubMed]

31. Vaz, J.A.; Almeida, G.M.; Ferreira, I.C.; Martins, A.; Vasconcelos, M.H. Clitocybe alexandri extract induces cell cycle arrest and apoptosis in a lung cancer cell line: Identification of phenolic acids with cytotoxic potential. Food Chem. 2012, 132, 482-486. [CrossRef] [PubMed]

32. Nunez, R. DNA measurement and cell cycle analysis by flow cytometry. Curr. Issues Mol. Biol. 2001, 3, 67-70. [PubMed]

33. Lecoeur, H.; Prevost, M.C.; Gougeon, M.L. Oncosis is associated with exposure of phosphatidylserine residues on the outside layer of the plasma membrane: A reconsideration of the specificity of the annexin v/propidium iodide assay. Cytometry 2001, 44, 65-72. [CrossRef]

34. Neves, M.P.; Cravo, S.; Lima, R.T.; Vasconcelos, M.H.; Nascimento, M.S.; Silva, A.M.; Pinto, M.; Cidade, H.; Correa, A.G. Solid-phase synthesis of 2'-hydroxychalcones. Effects on cell growth inhibition, cell cycle and apoptosis of human tumor cell lines. Bioorg. Med. Chem. 2012, 20, 25-33. [CrossRef] [PubMed]

35. Lima, J.M.; Sousa, D.; Lima, R.T.; Carvalho, A.M.; Ferreirad, I.C.F.R.; Vasconcelosa, M.H. Flower extracts of Filipendula ulmaria (L.) maxim inhibit the proliferation of the NCI-H460 tumour cell line. Ind. Crop. Prod. 2014, 59, 149-153. [CrossRef]

36. Preto, A.; Goncalves, J.; Rebocho, A.P.; Figueiredo, J.; Meireles, A.M.; Rocha, A.S.; Vasconcelos, H.M.; Seca, H.; Seruca, R.; Soares, P.; et al. Proliferation and survival molecules implicated in the inhibition of BRAF pathway in thyroid cancer cells harbouring different genetic mutations. BMC Cancer 2009, 9, 387. [CrossRef] [PubMed]

Sample Availability: Plant voucher specimens are available from the authors.

(C) 2016 by the authors; licensee MDPI, Basel, Switzerland. This article is an open access article distributed under the terms and conditions of the Creative Commons Attribution (CC-BY) license (http://creativecommons.org/licenses/by/4.0/). 